\title{
Moving up the Quality Ladder? EU-China Dynamics in Clothing
}

\author{
Hylke Vandenbussche \\ IRES-CORE, Université Catholique de Louvain, Louvain-la-Neuve, Belgium \\ Francesco Di Comite \\ European Commission, Joint Research Centre (JRC), Seville, Spain \\ Laura Rovegno \\ Center of Research in Economic Analysis (CREA), University of Luxembourg, Luxembourg \\ Christian Viegelahn \\ International Labour Organization (ILO), Employment Trends Unit, Geneva, Switzerland
}

\begin{abstract}
We apply a simple method to study the relative quality of Chinese versus European products exported in the clothing sector after the end of the Multi-Fiber Arrangement. Based on the model of Foster et al., (2008), we interpret the change in relative export prices and quantities sold in narrowly defined product categories as an indicator of quality shifts. Using UN Comtrade data, we find that European varieties exported to the US typically sell for a higher price than identical Chinese varieties exported to the US, but this price gap is narrowing. Despite rising prices, Chinese varieties are gaining market share. This opposite movement of relative prices and quantities sold in the same destination market are a strong indication of China's moving up the quality ladder in its clothing exports relative to the EU. While European core products in clothing are stable over time, Chinese exports show product dynamics with exit and entry of new core products every year.
\end{abstract}

JEL Classifications: F12, F13, F14

Key Words: Trade, Quality upgrading, Import competition, Product dynamics

\footnotetext{
* Corresponding Author: Hylke Vandenbussche; Department of Economics, IRES-CORE, Université Catholique de Louvain, Place Montesquieu 3, B-1348 Louvain-la-Neuve, Belgium; Tel: +32 010474137, Fax: +32 010473945, E-mail: hylke.Vandenbussche@uclouvain.be. Co-Authors: Francesco Di Comite; European Commission, Joint Research Centre (JRC), Institute for Prospective Technological Studies (IPTS), Calle Inca Garcilaso, 3 - E-41092 Seville, Spain; Tel: +34 954488371, Fax: +34 954488300, E-mail: francesco.di-comite@ec.europa.eu;

Laura Rovegno; Center of Research in Economic Analysis (CREA), University of Luxembourg, 162A, avenue de la Faïencerie - L-1511 Luxembourg; Tel: +352 4666446107, Fax: +352 4666446341, E-mail: laura.rovegno@uni.lu;

Christian Viegelahn; International Labour Organization (ILO) Office, Employment Trends Unit, Route des Morillons 4, CH-1211 Geneva, Switzerland; Tel: +41 227997264, Fax: +41 227997678, E-mail: viegelahn@ilo.org.
} 


\section{Introduction}

The general notion that many people have is that Europe exports high quality goods, while China exports low quality goods. This is related to Linder's (1961) hypothesis which states that richer countries export higher quality goods. ${ }^{1}$ If this is the case, Europe should not worry too much about adverse effects of competition. Vertical differentiation through quality differences softens price competition and allows firms at either end to survive and retain their market shares. One of the purposes of this paper is to see if the evidence in trade data is consistent with this perception. If European exports are indeed characterized by higher quality, we would expect prices of European products to be higher than Chinese ones. This is indeed what we find when comparing EU and Chinese exports in clothing to the rest of the world (RoW). However, this could also be explained by differences in product mix or destinations between European and Chinese exports. Thus, we also explore these possible determinants in our analysis. Another issue to keep in mind when comparing EU and Chinese export prices is whether a high price of European products can truly be associated with higher quality, or is a reflection of higher production and other costs. While cost and quality push prices in the same direction, their implications for sales are very different (Foster et al., 2008). To distinguish between cost and quality is not trivial. Here we take a simple and descriptive approach used in other empirical studies, which consists in comparing relative prices and quantities. The intuition behind this is the following. When the price of a relatively low-priced good goes up, while at the same time consumers buy more of it, the relative quality of that variety has increased. Despite its higher price, consumers buy more (Foster et al., 2008; Baldwin and Harrigan, 2011; Di Comite, Thisse, and Vandenbussche, 2011). In the opposite case when the price of an initially highpriced good comes down, but sales are not rising, its relative quality is decreasing.

In this paper we study one particular sector in detail, clothing. This sector is particularly interesting for various reasons. Firstly, clothing exports from China have increased rapidly, following China's entry into WTO in 2001. Secondly, clothing has for a long time experienced special treatment in the international trading system. When China entered the WTO, the clothing sector was still protected by the Multi-Fiber Arrangement (MFA from now on) which allowed developed economies like the EU and US to restrict their imports of clothing products. However, in 2005, the MFA came to an end, which marked the beginning of an increase in competition in the sector. Finally, the clothing sector is particularly interesting from an EU perspective given that this sector has for a long time been on decline both in terms of production and employment. ${ }^{2}$ The sector's strategy to increase innovation with a diversification towards

\footnotetext{
'See also Fajgelbaum et al., (2011), Hummels and Klenow (2005) and Latzer and Mayneris (2011).

2 According to Eurostat data, the clothing sector in EU15 (NACE C14) has seen negative growth rates in its volume of production, turnover, and employment for almost all years since 2000.
} 
high quality and specialty products (see European Commission, 2007) did not seem to have altered this trend considerably. The purpose of this paper is to see at a detailed product-level whether and how that increased competition has affected EU exports to the RoW and to a particular destination market relative to Chinese exports in the same HS6 digit product categories.

Our results suggest that the EU and China export the same types of clothing products to the RoW. This seems to be in line with Schott's (2008) findings. He reported that China and OECD countries have substantial overlap in the type of products they export to the US. For EU and Chinese clothing exports to the RoW, as we show in this paper, this also seems true. Our findings show that even after the MFA, which ended the protection of developed countries from imports of clothing products from developing countries, EU and China keep on exporting the same type of clothing products with an almost perfect product overlap.

The large overlap in product range that we observe in EU and Chinese exports suggests that price differences between these economies do not result from a different product mix, but rather from different prices within the same product (HS6) categories. When comparing EU and Chinese prices on a product-by-product basis, we find that, for the large majority of products, EU prices are higher than Chinese prices between 2000 and 2009. This is true when we compare prices of both economies to the RoW, or when we fix a particular destination market, the US. Our findings show that, while EU prices are consistently higher in narrowly defined product categories within clothing, EU sales are consistently lower than sales of similar products sold by the Chinese producers. With two countries producing the same good, the country which sees both its quantities and prices increase relative to the other country is likely to be experiencing relative improvements in the quality of the goods it produces. This is what we observe to be the case when comparing China to the EU. In recent years, Chinese export prices have been increasing relative to the European ones, while the sales of these Chinese products in narrowly defined categories within clothing have been going up relative to the European ones. Hence Chinese products are likely to have improved in quality, compared to European products.

The evidence provided seems to be consistent with an increase in the vertical differentiation of Chinese firms vis-à-vis European firms. Thus, the competition from Chinese products has likely intensified, also in terms of quality. Ever since the end of the MFA in 2005, EU prices and Chinese prices in clothing products have been converging, suggesting that price competition is tougher, making it more difficult for EU products to continue to price high in international markets. Moreover, we find a continuous alteration of "core" products on the Chinese side, not so much on the EU side. Whereas the EU's set of core products in terms of export value to RoW remained pretty stable over our period of analysis, this is not the case for China. China's core export products in 2000 were very different than its core products in terms of export value in 2009, indicating a high degree of product dynamics on the Chinese side. 


\section{Data and Methodology}

We use export data from the UN Comtrade database which contains product-level trade data at the HS6 digit level, for the period 2000 to 2009.

Prices are calculated from values and volumes, resulting in unit values. In order to make prices comparable across different products, we calculate unit values as a relative measure to the "world unit value". For example, if this measure takes a value of 2 , it means that prices are twice as large as the average price at which the product is sold in the world. If it is 1 , then prices are as high as the world average price.

Depending on the revision of the Harmonized System (HS), there are between 270 and 294 different HS6 products belonging to the clothing sector (HS codes starting with 61, 62, and 63). During the period of analysis, HS was revised twice. To account for this, we drop product lines where the correspondence across versions was many-to-many and prevented comparison across years. We also dropped observations where export quantities were not reported and hence unit values could not be calculated. This results in a sample of about 240 product lines representing around 92 and $96 \%$ of exports in the sector for China and the EU respectively.

Another difficulty is that the definition of the EU changed during the period of our analysis, due to the accession of new EU member states. To account for this we use a pragmatic approach and simply include all EU-15 countries into our EU definition, i.e. countries that were always part of the EU from 2000 to 2009. So what we refer to as EU exports in this paper, are always exports of EU-15, where we exclude exports from and to the new EU member states.

In our analysis we do not consider ownership effects, so we cannot differentiate between "true" Chinese products and those products that are assembled by say European firms in China and exported from China. Both types of products will occur in our data and may well explain some of the patterns we observe.

We focus on the clothing rather than on the textiles sector. The clothing sector is a sector that is typically constituted of final products while textile products are often considered as inputs into clothing. For example, textiles include product such as silk, wool and cotton (HS codes starting with 50,51 and 52 respectively), while clothing includes articles such as men's overcoats made of wool (610110), of cotton (610120) or of manmade fibers (610130). Given that the textile sector is predominantly an intermediate product sector with less opportunity for differentiation and price difference, we decided to focus on clothing products. 


\section{Comparing EU and China's Exports in Clothing to the Rest of the World}

\section{A. Export volumes, values, and prices}

This section compares total exports in clothing products by EU-15 and by China to the rest of the world (RoW) over the period 2000 2009. The comparison involves export volumes, values, and unit values.

It is clear from Figure 1a that before China's entry in WTO in 2001 its exports of clothing products were already much higher than that of the EU, suggesting that there might have been a comparative advantage of China in this sector even before it gained improved market access to the rest of the world. Ever since the entry of China into the WTO in 2001 Chinese exports of clothing have increased steeply, while EU exports have largely remained at their original level. The outbreak of the financial crisis in 2008, seems to have affected Chinese export volumes relatively more than the EU's, although both economies saw a similar decrease in their exports of clothing to the RoW in terms of value (Figure 1b).

Figure 1a. Quantity of clothing exports to the rest of the world

(Unit: Million Kilos)

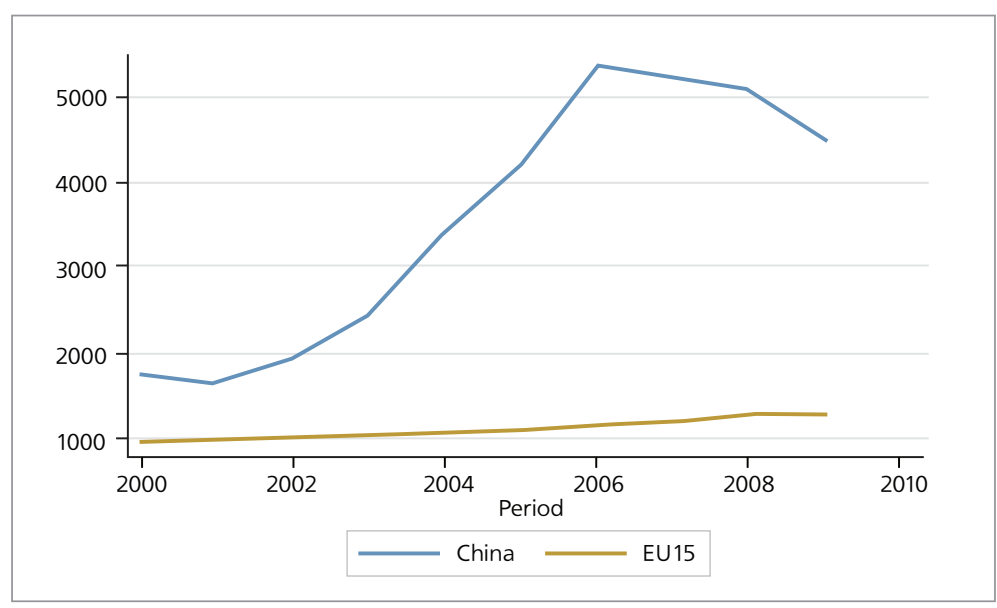

(Source) Authors' calculations using data from UN Comtrade. 
Figure $1 \mathrm{~b}$. Value of clothing exports to the rest of the world

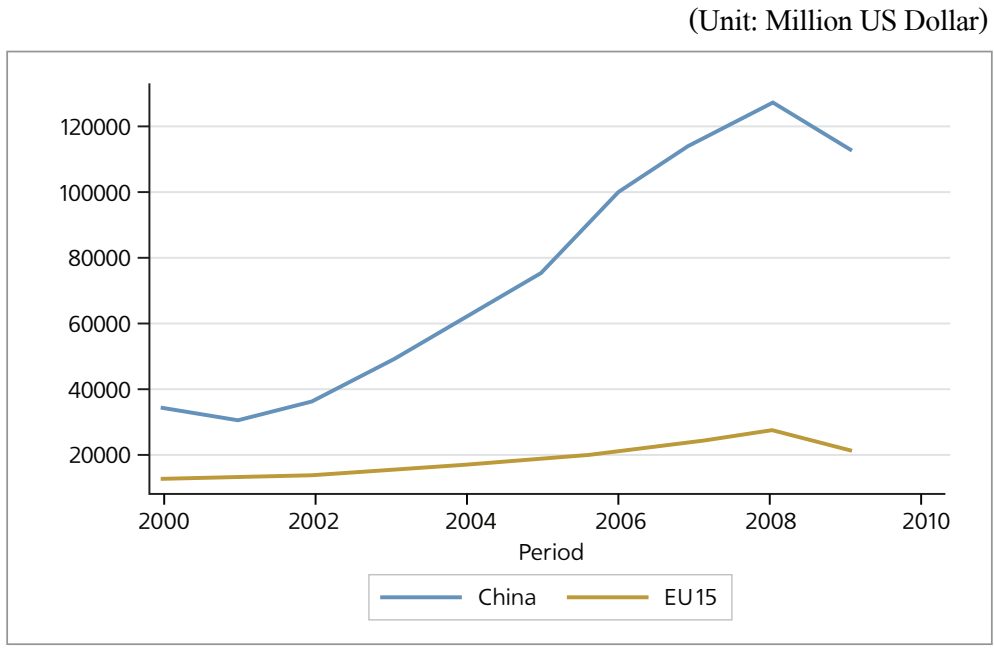

(Source) Authors' calculations using data from UN Comtrade.

For the large majority of clothing products within narrowly defined product categories (HS6), it can be noted that EU export prices are consistently above Chinese export prices throughout the sample period. This can be seen from Table 1, where for each year between 2000 and 2009, for around 80 90\% of the HS6 products exported, the unit value of EU exports exceeded that of the Chinese. In terms of the median price evolution within the clothing sector (Figure 2), European prices in clothing are falling since 2005, the year which marked the end of the MFA, whereas Chinese prices are on the rise, relative to the world prices.

A formal test of price convergence for the period 2005 2009 as a whole, as well as for each year, reported in Table 2 , confirms that this price convergence is statistically significant. ${ }^{3}$

\footnotetext{
${ }^{3}$ The convergence test consists in calculating the difference in EU and China export unit values for each 6-digit HS product and then testing whether these differences were equal in year $t$ with respect to year $t-1$ or $t-5$ using a one-sided t-test.
} 
Table 1. Unit Value Comparison EU-China in Clothing Products

(exports to the rest of the world, HS6)

\begin{tabular}{|c|c|c|c|}
\hline Year & $\begin{array}{c}\text { Total number of HS6 } \\
\text { products* }\end{array}$ & $\begin{array}{c}\text { Percentage of HS6 } \\
\text { for which EU unit } \\
\text { value }>\text { Chinese unit value }\end{array}$ & $\begin{array}{c}\text { Percentage of HS6 } \\
\text { for which Chinese unit } \\
\text { value }>\text { EU unit value }\end{array}$ \\
\hline 2000 & 241 & $82.6 \%$ & $17.4 \%$ \\
\hline 2001 & 233 & $82.4 \%$ & $17.6 \%$ \\
\hline 2002 & 231 & $84.8 \%$ & $15.2 \%$ \\
\hline 2003 & 231 & $85.7 \%$ & $14.3 \%$ \\
\hline 2004 & 241 & $91.7 \%$ & $8.3 \%$ \\
\hline 2005 & 241 & $91.7 \%$ & $8.3 \%$ \\
\hline 2006 & 241 & $93.4 \%$ & $6.6 \%$ \\
\hline 2007 & 209 & $91.4 \%$ & $8.6 \%$ \\
\hline 2008 & 215 & $84.7 \%$ & $15.3 \%$ \\
\hline 2009 & 220 & $77.3 \%$ & $22.7 \%$ \\
\hline
\end{tabular}

$($ Note $) *$ Number of HS6 products for which we have no missing values for quantities.

(Source) Authors' calculations using data from UN Comtrade.

Table 2. T-tests on convergence vs. divergence of $\mathbf{E} U$ and Chinese clothing unit values

\begin{tabular}{|c|c|c|c|l|}
\hline Period & $\begin{array}{c}\text { Average difference } \\
\text { in unit values, } \\
\text { year } 1^{\#}\end{array}$ & $\begin{array}{c}\text { Average difference } \\
\text { in unit values, } \\
\text { year 2 }\end{array}$ & $\begin{array}{c}\text { P-value } \\
\text { (convergence) }^{\S}\end{array}$ & \multicolumn{1}{|c|}{ Trend } \\
\hline $2005 \sim 2009$ & 0.850705 & 0.340920 & 0.00 & Convergence*** $^{* *}$ \\
\hline $2005 \sim 2006$ & 0.850705 & 0.804580 & 0.28 & Convergence $^{*}$ \\
\hline $2006 \sim 2007$ & 0.804580 & 0.637243 & 0.01 & Convergence*** $^{* *}$ \\
\hline $2007 \sim 2008$ & 0.637243 & 0.486857 & 0.03 & Convergence $^{* *}$ \\
\hline $2008 \sim 2009$ & 0.486857 & 0.340920 & 0.03 & Convergence** $^{* *}$ \\
\hline
\end{tabular}

(Note) ${ }^{\#}$ Average difference between EU and Chinese export unit values in the first year indicated in the first column (difference 1), ${ }^{\#}$ Same for the second year indicated (difference 2). ${ }^{\S}$ Correspond to the t-test with $\mathrm{H}_{0}$ : difference $1=$ difference $2, \mathrm{H}_{A}$ : difference $1>$ difference 2 , that is, convergence.

(Source) Authors' calculations using data from UN Comtrade. 
Figure 2. Relative unit values of clothing exports to the rest of the world (Unit: median)

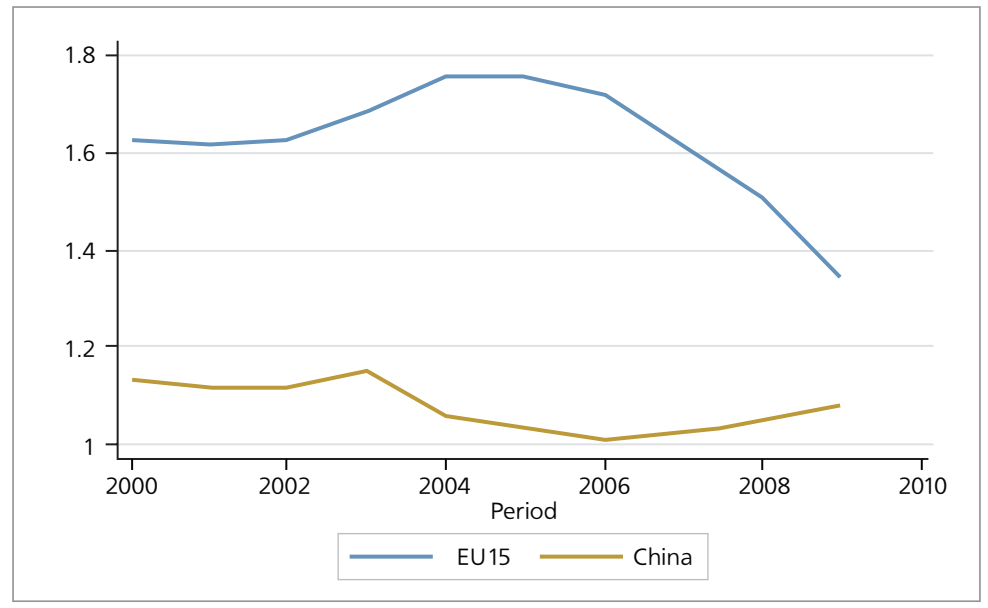

(Source) Authors' calculations using data from UN Comtrade.

\section{B. Product overlap and product mix similarity}

Similar to Schott (2008) for the US, we verify to what extent the EU and China specialize in different product categories within the clothing industry. Surprisingly, when comparing their exports in HS6 categories to the RoW, we find that the range of exported products overlaps perfectly in the sense that both economies export an identical set of products. Indeed, in Table 3 we report the number of products that are exported by both the EU and China versus the number of products that are exported only by the EU or only by China. We see that all products are exported by both economies in all years. Put differently, both the EU and China export in every HS6 digit product category within the clothing sector, which is consistent with Schott's (2008) results when comparing Chinese and OECD exports to the US. ${ }^{4}$

Thus far, we have only counted the number of products exported by both. But a complementary question is to what extent the EU and China differ in terms of the values of the products they export. To explore this issue we use the Finger-Kreinin (1979) index which can give an idea of the overlap of the export portfolios of two economies in a specific industry. ${ }^{5}$ The index lies between 0 and 1. A value closer to 1 indicates similarity in export portfolios between China and the EU, accounting for the relative importance of each product in terms of export shares. We find the Finger-Kreinin index for clothing to lie around 0.58 for the entire sample

\footnotetext{
${ }^{4}$ Of course, we cannot rule out that differences exist at lower levels of product aggregation which cannot be observed.

${ }^{5}$ The Finger-Kreinin-index is calculated as $\sum_{i \in l} \min \left(s h_{i C H N}, s h_{i E U t}\right)$, where $s h_{i C H N t}$ and $s h_{i E U t}$ are the shares of product $i$ in year $t$ in total Chinese and EU exports respectively.
} 
period, suggesting that while both EU and China are present in each product category, their exports are different, with little indication that this is changing over time.

We now turn to the dispersion of EU and Chinese export values across 6-digit HS products. To this end Table 4 reports the standard deviation and inter-quartile range of export shares as well as the Gini index for export values. Results do not show remarkable differences in the dispersion of export shares between EU and China. The Gini index for Chinese export values is somewhat smaller than that of EU exports, suggesting that the latter are more concentrated. Also, there seems to be an upward trend in this index for both EU and Chinese exporters suggesting increasing concentration for both exporters. However, the differences are very small which leads us to conclude that the overall level of concentration of export values of China and EU are very similar.

Table 3. Total clothing exports to the rest of the world

\begin{tabular}{|l|l|l|l|l|l|l|l|l|l|l|}
\hline Year & 2000 & 2001 & 2002 & 2003 & 2004 & 2005 & 2006 & 2007 & 2008 & 2009 \\
\hline Exported by both & 292 & 292 & 294 & 294 & 294 & 294 & 294 & 271 & 271 & 271 \\
\hline EU-only & 0 & 0 & 0 & 0 & 0 & 0 & 0 & 0 & 0 & 0 \\
\hline China-only & 0 & 0 & 0 & 0 & 0 & 0 & 0 & 0 & 0 & 0 \\
\hline
\end{tabular}

(Note) The table reports the number of 6-digit HS codes for which both EU and China report non-zero export values. (Source) Authors' calculations using data from UN Comtrade.

Table 4. Descriptive statistics on the dispersion of export shares in clothing

\begin{tabular}{|c|cccc|cccc|}
\hline & \multicolumn{5}{|c|}{ EU } & \multicolumn{4}{c|}{ China } \\
\hline & \multicolumn{3}{|c}{ Standard } & Inter- & quartile & & \multicolumn{3}{c|}{ Inter- } \\
Year & Mean & Deviation & range & Gini Index & Mean & $\begin{array}{c}\text { Standard } \\
\text { Deviation }\end{array}$ & $\begin{array}{c}\text { quartile } \\
\text { range }\end{array}$ & Gini Index \\
\hline 2000 & 0.0041 & 0.0073 & 0.0036 & $67.4 \%$ & 0.0041 & 0.0071 & 0.0039 & $66.0 \%$ \\
2001 & 0.0041 & 0.0074 & 0.0036 & $67.6 \%$ & 0.0043 & 0.0069 & 0.0042 & $64.0 \%$ \\
2002 & 0.0041 & 0.0072 & 0.0038 & $67.9 \%$ & 0.0043 & 0.0072 & 0.0043 & $64.6 \%$ \\
2003 & 0.0041 & 0.0072 & 0.0039 & $68.0 \%$ & 0.0043 & 0.0072 & 0.0043 & $64.9 \%$ \\
2004 & 0.0041 & 0.0073 & 0.0036 & $69.1 \%$ & 0.0041 & 0.0068 & 0.0038 & $65.0 \%$ \\
2005 & 0.0041 & 0.0073 & 0.0038 & $69.5 \%$ & 0.0041 & 0.0076 & 0.0041 & $67.0 \%$ \\
2006 & 0.0041 & 0.0072 & 0.0037 & $69.2 \%$ & 0.0041 & 0.0078 & 0.0041 & $67.8 \%$ \\
2007 & 0.0041 & 0.0071 & 0.0038 & $68.5 \%$ & 0.0048 & 0.0089 & 0.0047 & $67.1 \%$ \\
2008 & 0.0041 & 0.0072 & 0.0036 & $69.1 \%$ & 0.0047 & 0.0080 & 0.0048 & $66.2 \%$ \\
2009 & 0.0041 & 0.0072 & 0.0041 & $68.8 \%$ & 0.0045 & 0.0082 & 0.0047 & $67.2 \%$ \\
\hline
\end{tabular}

(Note) The mean, standard deviation and inter-quartile range are calculated using the share of each 6-digit HS code in total export value. The Gini index is calculated using the export value of each 6-digit HS code.

(Source) Authors' calculations using data from UN Comtrade. 


\section{Core products}

This section aims to identify the exports which are "core" for the EU and for China to the extent that they represent the top $10 \%$ centile of export shares. The questions we are interested in are 1) did "core" products change over time?; 2) are "core" products overlapping?; 3) has the overlap of Chinese and EU "core" products been increasing over time?

Some of our findings are illustrated in Figure 3 and can be summarized as follows. For the EU we find that the HS6 digit products representing the top 10\% centile of export value in the starting year of our analysis i.e. the year 2000, still represent a high share of export value in the final year of our analysis, 2009. In contrast, China's core products changed much more during that same period. The products belonging to the top $10 \%$ of export value in the year 2000, no longer represented a large share of export value in 2009. Interestingly, the share of EU-2000 core products in Chinese exports in the year 2000 increased over time, suggesting that, at least for core products, China's export mix became relatively closer to the EU's. However, while EU core products which did not change much over time gained in importance in China's export portfolio, the overlap in clothing products between China and EU in the final year 2009 remains small. In sum, product dynamics in clothing appear much stronger for China than for the EU.

Figure 3. Share of core products in clothing export value

(exports to the rest of the world)

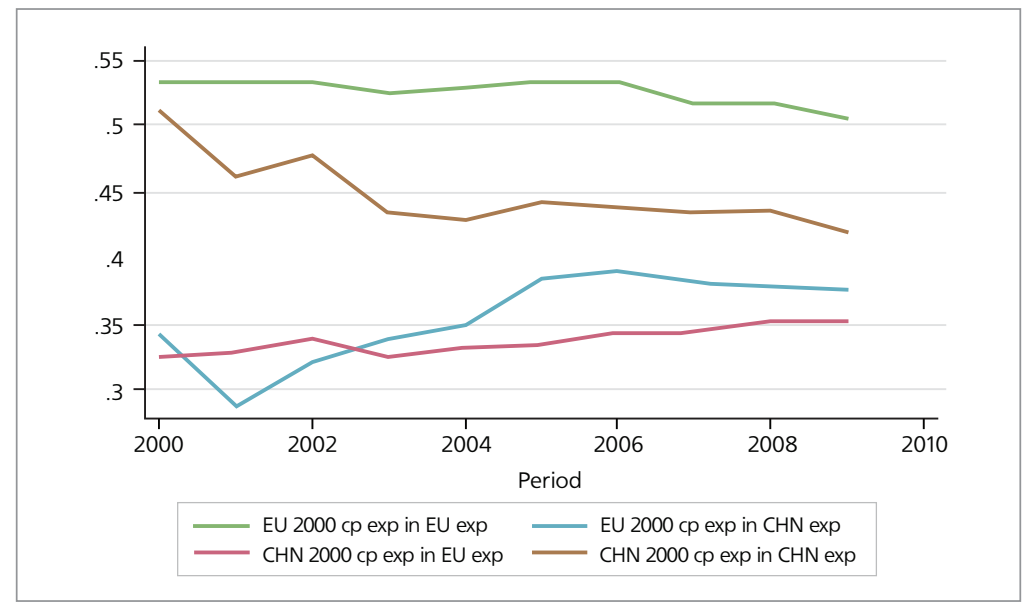

(Note) Core products (CP) are defined as the $10 \%$ of clothing products with the highest value of exports for each exporter in 2000. This basket of core products is defined separately for China and the EU and kept fixed throughout the period. The figure presents the evolution of the share of both core product baskets in total export values.

(Source) Authors' calculations using data from UN Comtrade.

When looking at unit values of core products in Figure 4, we notice a clear distinction. For 
the EU we find that average export unit values of both its own core products and China's core products have a similar magnitude and evolution. However, we find that Chinese exports of its core products appear to have higher unit values than Chinese exports of EU core products. This seems to correspond with the phenomenon described in international trade as "shipping the good apples out", where countries export products of high quality, explaining the relatively high unit value. In this sense, the challenge for emerging countries' entrepreneurs appears to be that they have to produce goods of sufficiently high quality in order to gain access to foreign markets, where standards can be more stringent or consumers are more sophisticated.

\section{Figure 4. Core product unit values of clothing}

(exports to the rest of the world)

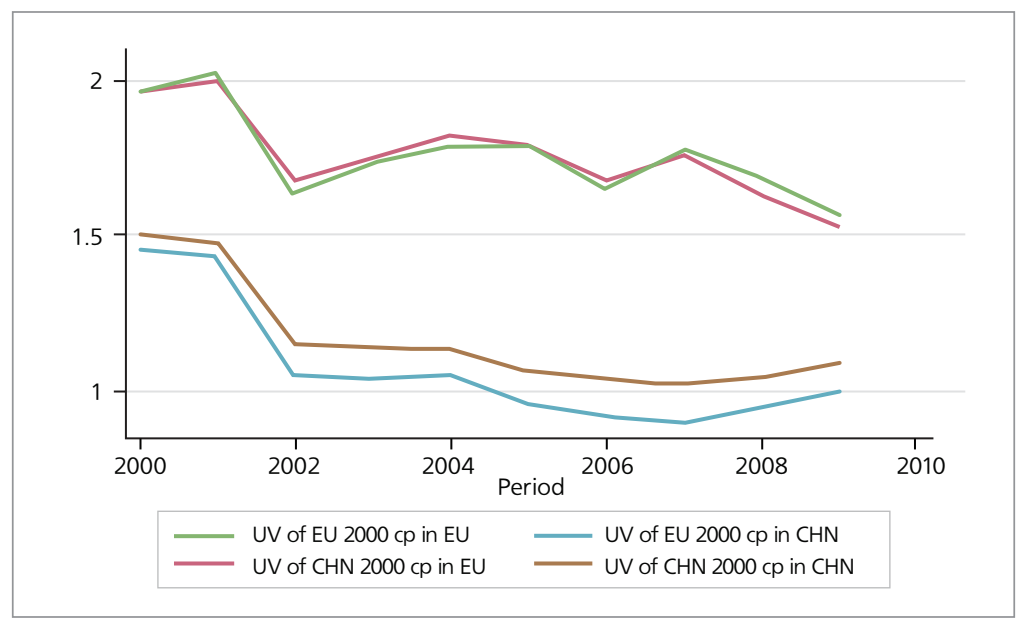

(Note) Core products (CP) are defined as the $10 \%$ of clothing products with the highest value of exports for each exporter in 2000. This basket of core products is defined separately for China and the EU and kept fixed throughout the period.

(Source) Authors' calculations using data from UN Comtrade.

\section{Price versus Quantity Analysis}

It is a well-established practice in the domain of international trade to exploit prices and price dynamics to extract information on product characteristics. For a seminal contribution, see Armington (1969). However, we know that prices are affected by both demand and supply factors (Foster et al., 2008). This implies that the observation of higher prices alone cannot be used as an indication of higher quality in isolation, but it needs to be complemented with an effort to disentangle the two different sources of price differentials. One way to distinguish 
cost from quality aspects involved in prices is to consider quantity sold, since costs and quality have a very different effect on quantities sold (Di Comite et al., 2011). ${ }^{6}$ Looking at trade from the viewpoint of monopolistic competition, prices are the results of firms' optimal behavior in terms of profit maximization. This means that there are only two reasons why prices can be high: either high demand, possibly driven by high quality, or high marginal costs of production. However, when high prices are the result of high quality embedded in the product, this high quality will shift demand out and result in high sales and prices. On the contrary, when prices are high because of high costs, low quantities sold will ensue. To sum up, the combination of prices and corresponding quantities sold tells us whether quality or cost is driving the price pattern that we observe.

\section{A. A simple model to study relative quality}

A model that clearly makes this point is the one by Foster et al., (2008), who develop a simple model of monopolistic competition with non-constant markups and vertical differentiation, or "quality", based on Melitz and Ottaviano (2008). The industrial structure of the clothing sector is typically characterized by a high number of relatively small firms that are not big enough to affect world prices of clothing or collude on the entire global market but still enjoy some market power on the particular variety they sell. As a consequence, monopolistic competition seems an ideal modeling framework to study "clothing".

Of the many alternative models of monopolistic competition, though, few have the interesting property of allowing prices not to depend on productive efficiency alone or market-specific demand parameters. In Foster et al., (2008), demand shifters that can be interpreted as quality enter consumers' utility as a variety-specific parameter denoting the willingness to pay for the first unit of the good. ${ }^{7}$ Given the nature of our data, a variety here is considered a HS6-exporting market combination (i.e. a given EU and a Chinese HS6 represent the same product but different varieties). A convenient way of expressing consumers' preferences is the following:

$$
U=\int_{s \in S} \alpha_{s} q_{s} d s-\frac{\beta}{2} \int_{s \in S} q_{s}^{2} d s-\frac{\gamma}{2}\left[\int_{s \in S} q_{s} d s\right]^{2}+q_{0}
$$

$q_{s}$ represents the amount consumed of variety $s \in S$, where $s$ denotes the country where the good was produced, in our case China or the EU, and $S$ is the total mass of varieties available to con-

\footnotetext{
${ }^{6}$ Note that here we do not assume any correlation between quality and marginal cost in order to consider their effects separately. This is equivalent to assuming that quality is generated through fixed outlays such as R\&D expenses, which do not affect equilibrium prices.

${ }^{7}$ With more detailed information on costs of production, it would have been possible not only to identify quality trends, but also pure quantity shifters in the demand function, such as in Di Comite et al., (2011). In the current context, we just need to base our analysis on the assumption that there are no idiosyncratic quantity shifters affecting European clothing exports vis-à-vis Chinese ones, but that the entire difference runs through the demand shifters.
} 
sumers in a particular market.

The first parameter, $\alpha_{s}$, captures the intrinsic quality of a variety: the higher $\alpha_{s}$, the higher the utility that consumers all over the world derive from the consumption of that particular variety $s$ of the good. The second parameter, $\beta$, can be seen as reflecting the degree of product differentiation in the clothing sector: the higher $\beta$ implies that varieties are perceived as being more differentiated. As a consequence, consumers are willing to pay more for each of them, which in turns results in lower quantities sold for each variety. The third parameter, $\gamma$, denotes the substitutability between varieties of the same good: the higher $\gamma$, the lower amount of utility consumers enjoy from the consumption of a particular variety when they are already consuming different varieties of the same good. See Di Comite et al., for an extensive analysis of the function and its parameters. The last term, $q_{0}$, is simply a numéraire good representing all the other goods consumed in the economy.

As usual in monopolistic competition models, firms are not supposed to interact strategically and consider the behavior of other firms in the market as given. The competitive environment experienced by each variety is then affected by the optimal pricing strategies of the competitors which are, in turn, determined by the distribution of structural parameters. Standard aggregate indicators can be used to capture the interactions between each firm and the market at large.

Once consumers and firms optimize their behavior, the former subject to a standard budget constraints and the latter considering a simple profit function, $\pi_{\mathrm{s}}=\left(p_{s}-c_{s}\right) q_{s}-f_{s}$, optimal prices and quantities can be expressed as:

$$
p_{s}^{*}=\frac{\alpha_{s}+c_{s}}{2}-\left(\frac{\gamma N}{2 \beta+\gamma N}\right) \frac{\bar{\alpha}-\bar{c}}{2}
$$

and

$$
q_{s}^{*}=\frac{1}{\beta}\left[\frac{\alpha_{s}-c_{s}}{2}-\left(\frac{\gamma N}{2 \beta+\gamma N}\right) \frac{\bar{\alpha}-\bar{c}}{2}\right]
$$

Where $\alpha, \beta$ and $\gamma$ are the same parameters representing, quality, product differentiation and substitutability of a variety $s$ respectively. $N$ is the number of competing varieties in product market $S$ in a particular destination market and $\bar{\alpha}$ and $\bar{c}$ are average quality and average marginal cost of other firms operating in the same product and destination market. When fixing a particular destination market like the US, we control for all the price and quantity determinants that EU and Chinese varieties have in common when selling to the same destination market and that feature in the second terms on the right hand side in the above expressions.

In contrast, the first term on the right-hand side from the above expressions, contain variety specific determinants of price and quantity. It can already be noted that a variety's quality $\left(\alpha_{s}\right)$ has a positive effect on both price and quantity, while marginal cost $\left(C_{s}\right)$ raises price but lowers quantity. Hence, a comparison of relative price and quantity dynamics of Chinese versus 
European varieties in the same destination market is informative about the relative importance of quality versus cost evolutions at the variety level.

\section{B. Observations and predictions}

The equilibrium prices and quantities of the Foster et al., (2008) model turn out to be useful to shed some light on the quality upgrading dynamics of Chinese and EU exporters to a third destination market, say the US, noting that

$$
\frac{\partial p_{s}^{*}}{\partial \alpha_{s}}>0 ; \quad \frac{\partial p_{s}^{*}}{\partial c_{s}}>0 ; \quad\left|\frac{\partial p_{s}^{*}}{\partial \alpha_{s}}\right|=\left|\frac{\partial p_{s}^{*}}{\partial c_{s}}\right|
$$

but

$$
\frac{\partial q_{s}^{*}}{\partial \alpha_{s}}>0 ; \quad \frac{\partial q_{s}^{*}}{\partial c_{s}}<0 ; \quad\left|\frac{\partial q_{s}^{*}}{\partial \alpha_{s}}\right|=\left|\frac{\partial q_{s}^{*}}{\partial c_{s}}\right|
$$

Hence, a variety's quality $\left(\alpha_{s}\right)$ has a positive effect on both equilibrium price and quantity, while marginal cost $\left(C_{s}\right)$, raises price but lowers quantity. Thus, while price movements alone are not sufficient to identify whether cost or quality is the source of the rise, they are sufficient when observed in combination with quantity movements. For example, rising prices can either be a reflection of lower efficiency (higher costs) or higher quality or both. But in combination with quantity movements we can identify the source of the price rise. If rising prices coincide with lower sales, this is a reflection of higher costs. On the other hand, if rising prices coincide with higher quantity sold, the Foster et al., (2008) model would suggest that the quality determinant is a more important explanation of the price rise.

\section{EU vis-à-vis China: Comparison over time}

Evaluating the relative export performance of the EU and China towards a specific market and tracing the evolution of their unit prices and quantities shipped, we get an idea on the evolution of quality and costs in the period considered. More precisely, we can determine which one of the two price components i.e. quality or costs had a bigger impact on the comparative evolution of unit values and volumes shipped from EU and China to third countries over time to determine in which direction quality and costs with respect to the competitor have evolved: 


$$
\begin{gathered}
p_{E u}^{*}-p_{C \text { hina }}^{*}=\frac{\left(\left(\alpha_{E u}+c_{E u}\right)-\left(\alpha_{C h i n a}+c_{C h i n a}\right)\right)}{2} \\
\Delta\left(p_{E u}^{*}-p_{C h i n a}^{*}\right)=\frac{\left(\Delta\left(\alpha_{E u}-\alpha_{C h i n a}\right)+\Delta\left(c_{E u}-c_{C h i n a}\right)\right)}{2}
\end{gathered}
$$

and

$$
\begin{gathered}
q_{E u}^{*}-q_{\text {China }}^{*}=\frac{\left(\left(\alpha_{E u}+c_{E u}\right)-\left(\alpha_{C h i n a}+c_{C h i n a}\right)\right)}{2 \beta} \\
\Delta\left(q_{E u}^{*}-q_{C h i n a}^{*}\right)=\frac{\left(\Delta\left(\alpha_{E u}-\alpha_{C h i n a}\right)+\Delta\left(c_{E u}-c_{C h i n a}\right)\right)}{2 \beta}
\end{gathered}
$$

Looking at relative (EU vis-à-vis China) variations over time in prices and quantities, thefollowing theoretical implications on the dominating effects can be drawn $\left(\Delta x_{i}=x_{i, t}-x_{i, t-1}\right.$ where $x=p, q$ and $i=E U$ or China)

- If $\Delta q_{E u}>\Delta q_{\text {China }}$ and $\Delta p_{E u}>\Delta p_{\text {China }} \Rightarrow$ European exporters are improving their quality ( $\left.\uparrow \alpha\right)$ with respect to Chinese exporters;

- If $\Delta q_{E u}<\Delta q_{\text {China }}$ and $\Delta p_{E u}<\Delta p_{\text {China }} \Rightarrow$ European exporters are reducing their quality advantage $(\downarrow \alpha)$ with respect to Chinese exporters;

- If $\Delta q_{E u}>\Delta q_{\text {China }}$ and $\Delta p_{E u}<\Delta p_{\text {China }} \Rightarrow$ European exporters are improving their efficiency $(\downarrow c)$ with respect to Chinese exporters;

- If $\Delta q_{E u}<\Delta q_{\text {China }}$ and $\Delta p_{E u}>\Delta p_{\text {China }} \Rightarrow$ European exporters are losing cost competitiveness $(\uparrow c)$ with respect to Chinese exporters;

To see which of the above scenarios applies, we plot prices and quantities for all HS6 digit clothing products exported by EU and China to RoW in Figure 5 for 2000, 2005 and 2009, corresponding to the first, middle and final year of our data. Each dot represents the relative position of EU price and quantity versus China for a particular HS6 product. 
Figure 5. Relative quantities and unit values, EU vs. China

(for clothing exports to the rest of the world)

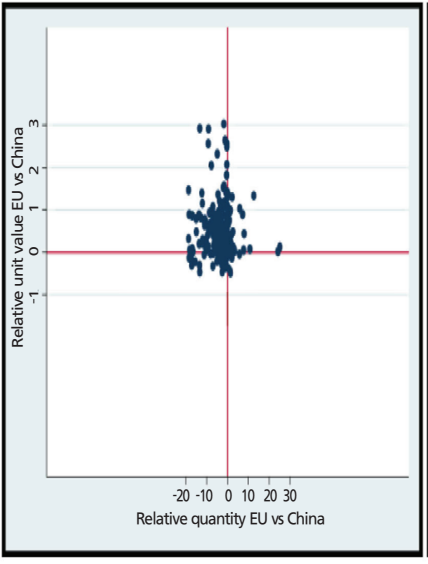

in 2000

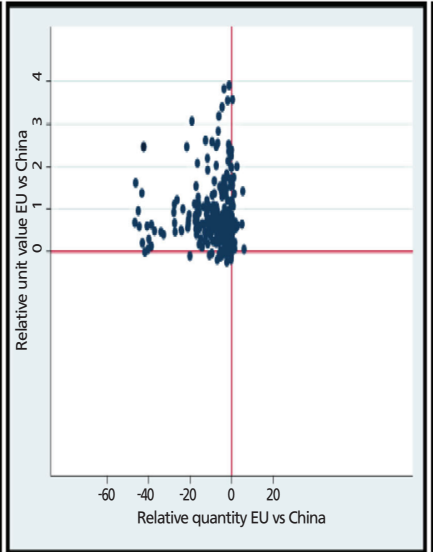

in 2005

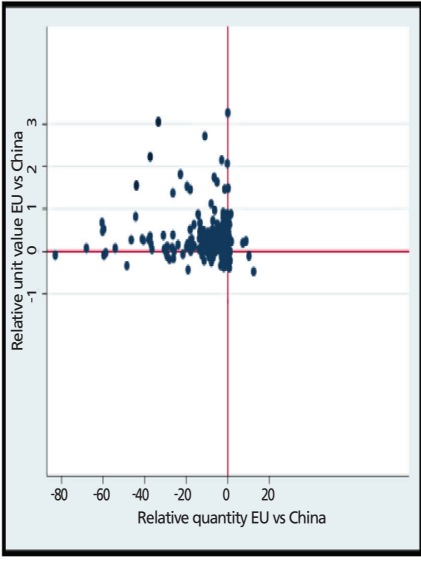

in 2009

(Note) A positive (negative) value on the horizontal axis means that European quantities in a particular HS6 is higher (is lower) than the Chinese quantity of the same HS6 to the rest of the world. Similarly, for prices on the vertical axis, a positive (negative) value means that the European price is higher (is lower) than the Chinese price for the same HS6.

(Source) Authors' calculations using data from UN Comtrade.

The relative quantity that is shown along the horizontal line in Figures 5 is calculated as follows:

$$
\begin{gathered}
\frac{Q^{E U}}{Q^{C H}}-1 \text { if } Q^{E U}>Q^{C H} \\
-\left(\frac{Q^{C H}}{Q^{E U}}-1\right) \quad \text { if } Q^{E U}<Q^{C H}
\end{gathered}
$$

where $Q^{E U}$ and $Q^{C H}$ are the quantities exported by EU and China respectively. Therefore, the dots in the left-hand panel of the figures represent products for which the quantity exported by China is larger, while those to the right are products for which EU exports are larger in quantity. The distance between each dot and the central axis shows how large this difference is in percentage. A similar measure is used for relative unit values:

$$
\begin{gathered}
\frac{U V^{E U}}{U V^{C H}}-1 \quad \text { if } U V^{E U}>U V^{C H} \\
-\left(\frac{U V^{C H}}{U V^{E U}}-1\right) \quad \text { if } U V^{E U}<U V^{C H}
\end{gathered}
$$


where $U V{ }^{E U}$ and $U V^{C H}$ are the export unit values for EU and China respectively. So products where the unit value of EU export is higher are represented in the upper panel, while the lower panel presents those for which the Chinese export unit value is higher.

It becomes clear that in 2009 , observations on quantity are situated more on the left hand side of the figure, suggesting that the relative sales of EU products vis-à-vis the Chinese sales in terms of quantities have fallen compared to previous years. The fact that relative EU prices are situated above the horizontal line suggests that EU prices are relatively higher than Chinese prices. So EU products are keeping higher prices and selling less over time. These results suggest decreasing quality differences between EU and Chinese exports (depressing both prices and quantities of EU against Chinese exports) between 2005 and 2009. The trends observed for the years between 2000 and 2005 indicate higher cost differences between European and Chinese exporters with prices diverging and quantity differences increasing, i.e., for Chinese merits or European demerits.

\section{The US market}

In our comparison of unit values, we have ensured that the higher unit values we find for the EU are not driven by the product composition since both the EU and China are present in all product categories. Moreover, instead of comparing average unit values across HS6 digit products, we have instead compared unit values within the same HS6 digit products. However, the higher unit values we find for EU exports of similar HS6 digit products could still be the result of a different country-mix. Given that we have thus far analyzed EU and China's exports to the RoW, we cannot exclude that this price difference is driven by the fact that the EU may be selling to a different set of countries than China. Suppose that the EU is typically exporting products to developed countries, whereas China mainly exports to developing countries, then it would not be a surprise that EU unit values are higher than China's which would simply reflect the fact of different incomes and market characteristics in destination countries. To accommodate for the country-mix, and to make the price comparison more meaningful, we should compare EU and China's exports in the same destination market. A comparison of prices and quantities in the same destination market, therefore, seems more warranted.

\section{A. Prices and quantities exported to the US market}

We therefore repeat our analysis of prices and quantities presented in Figure 5 but limit our attention to EU and Chinese exports in clothing to the US market. This is presented in Figure 6. Interestingly, the results obtained earlier for exports to RoW are also present when comparing 
EU and Chinese exports to the same destination market, i.e., the US. Again we see that in 2009, observations lie in the top left quadrant of Figure 6, suggesting that while EU prices are higher than Chinese prices, EU quantities are lower. Our earlier results do not seem to be driven by a country mix effect. Again, it can be noted that in 2000 EU exports to the US were more expensive than Chinese, but volumes were more similar and even higher for many Chinese HS6 products. In 2005, as the US market became more and more open to Chinese exports, the price difference between European and Chinese products increased, while quantities of European products decreased compared to Chinese products (the dots are shifted upwards and leftwards). This is again indicative of a widening cost difference, causing relatively inefficient European products to lose market share with respect to Chinese competitors. Finally, in 2009 the movement is more leftwards and downwards, indicating a reduction in price differences and a further loss of EU market shares vis-à-vis Chinese exporters. This suggests that quality differences are decreasing while cost differences may be still increasing. ${ }^{8}$

It is reassuring for our results to observe the same qualitative trends for EU and Chinese exports whether we focus on the RoW or on a single destination market such as the US.

Figure 6. Relative quantities and unit values, EU vs. China

(for clothing exports to the US)

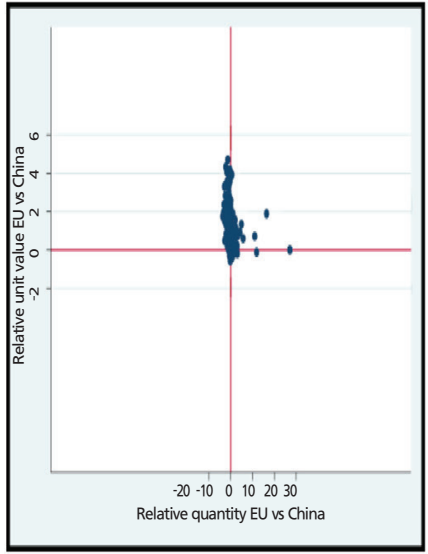

in 2000

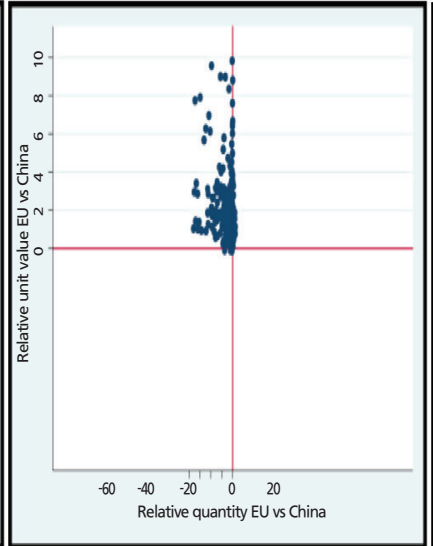

in 2005

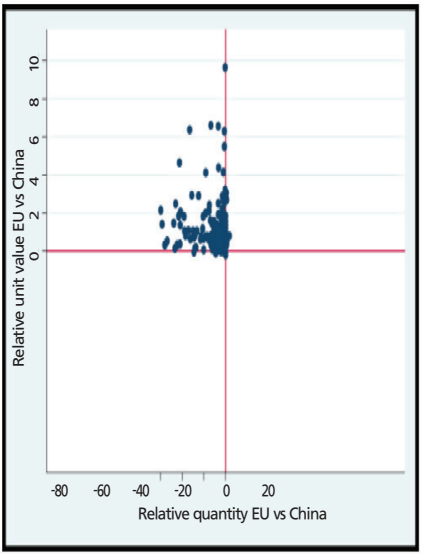

in 2009

(Note) A positive (negative) value on the horizontal axis means that European quantities in a particular HS6 is higher (is lower) than the Chinese quantity of the same HS6 to the US market. Similarly, for prices on the vertical axis, a positive (negative) value means that the European price is higher (is lower) than the Chinese price for the same HS6.

(Source) Authors' calculations using data from UN Comtrade.

\footnotetext{
${ }^{8}$ These trends are similar even when considering destination markets with different income levels and different income distributions such as Brazil and Mexico in which we compare the relative performance of European and Chinese HS6 digit products.
} 


\section{B. Product dynamics and unit values on the US market}

As shown in Table 5, product dynamics of EU and Chinese exports in clothing to the US market are low. Most HS 6-digit products that were exported as early as 2000, are still present ten years later. Very few, if any products are added or dropped.

Table 5. Number of newly exported, continuously exported, and dropped

(Clothing exports to the US)

\begin{tabular}{|l|cccccccccc|}
\hline Year & 2000 & 2001 & 2002 & 2003 & 2004 & 2005 & 2006 & 2007 & 2008 & 2009 \\
\hline EU, current year only $^{1}$ & 0 & 0 & 0 & 0 & 0 & 0 & 1 & 0 & 0 & 0 \\
\hline EU, Previous and current years $^{2}$ & 246 & 246 & 246 & 246 & 245 & 245 & 245 & 246 & 246 & 245 \\
\hline EU, Previous year only $^{3}$ & 0 & 0 & 0 & 0 & 1 & 0 & 0 & 0 & 0 & 1 \\
\hline China, Current year only $^{1}$ & 5 & 0 & 2 & 1 & 2 & 1 & 0 & 0 & 0 & 0 \\
\hline China, Previous and current years $^{2}$ & 240 & 244 & 243 & 243 & 243 & 245 & 246 & 246 & 246 & 246 \\
\hline China, Previous year only $^{3}$ & 0 & 1 & 1 & 2 & 1 & 0 & 0 & 0 & 0 & 0 \\
\hline Always Both $^{4}$ & 235 & 235 & 235 & 235 & 235 & 235 & 235 & 235 & 235 & 235 \\
\hline
\end{tabular}

(Note) ${ }^{1}$ Number of 6-digit HS codes exported in the current year and not exported the year before, ${ }^{2}$ number of 6-digit HS codes exported both in the current and previous years, ${ }^{3}$ number of products exported in the previous year but not the current year, ${ }^{4}$ number of products exported both by EU and China every year.

(Source) Authors' calculations using data from UN Comtrade.

However, when focusing our attention on "core products" only (Figure 7), we see that the HS6 digits in the top $10 \%$ centile of export shares show a very different evolution over time for EU exports versus Chinese exports to US. European top 10\% core products in 2000 represented $58 \%$ of EU exports to the US and these same products still accounted for almost $50 \%$ of the EU export value to the US ten years later. The Chinese product mix in contrast, changed much more over time. Whereas the top $10 \%$ of products in 2000 accounted for $65 \%$ of Chinese export value to the US in 2000 , these same products represent only $35 \%$ of exports to the US in 2009, suggesting that other products became much more important in China's exports to the US. 


\section{Figure 7. Share of core products in clothing export value}

(exports to the US)

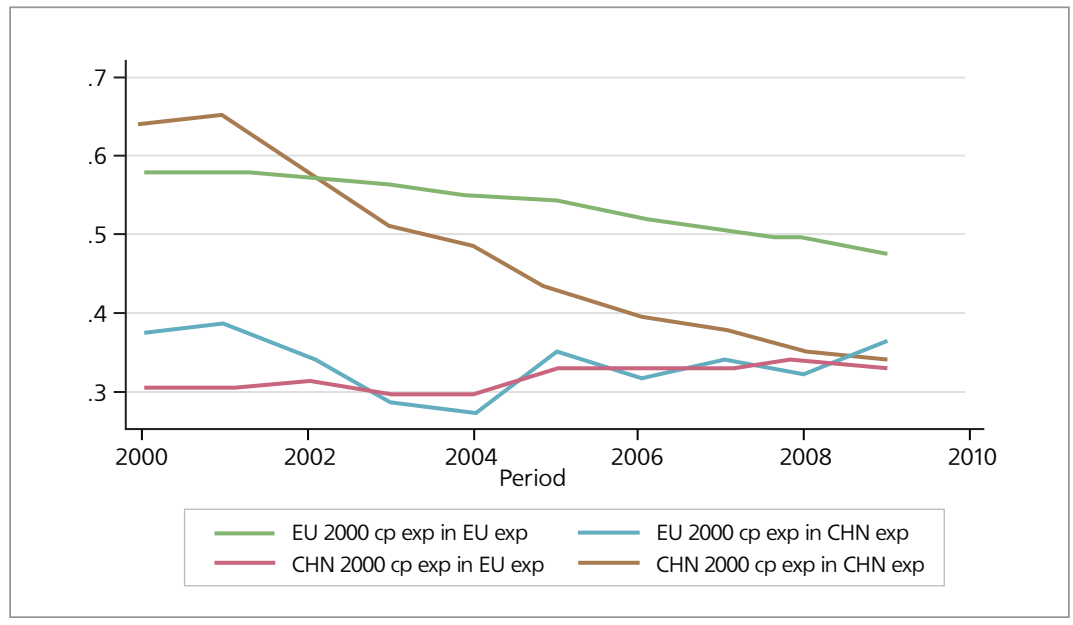

(Note) Core products are defined as the $10 \%$ of clothing products with the highest value of exports to the US in 2000. This basket of core products is defined separately for China and the European Union and kept fixed throughout the period. The figure presents the evolution of the share of both core product baskets in total export values.

(Source) Authors' calculations using data from UN Comtrade.

In terms of unit values (Figure 8), we see that the median unit value for EU products always lies above the median Chinese unit value on the US market. In order to avoid that the average unit value differences are driven by changes in the product composition, we only include in the comparison those products that are exported by both EU and China to the US. Also, by comparing prices on the same destination market, we are confident that the unit value difference, also found for exports of EU and China to RoW, is not driven by a country composition effect. Just like with the rest of the world, the median unit value in Figure 8 reflects a higher price of EU products on a product-by-product basis for the majority of HS6 digit products included in the comparison. Table 6 reports the number of products comparing export unit values, and confirms what was found for export to the RoW, i.e., that for the vast majority of products exported to the US, the unit value of EU exports is higher than that of Chinese exports. 
Table 6. Unit value comparison of EU-China

(Clothing exports to the US)

\begin{tabular}{|c|c|c|c|}
\hline Year & $\begin{array}{c}\text { Number of HS6 } \\
\text { products }^{1}\end{array}$ & $\begin{array}{c}\text { Number of HS6 EU unit } \\
\text { price }>\text { Chinese unit price }\end{array}$ & $\begin{array}{c}\text { Number of HS6 Chinese unit } \\
\text { price }>\text { EU unit price }\end{array}$ \\
\hline 2000 & 240 & 221 & 19 \\
\hline 2001 & 231 & 212 & 19 \\
\hline 2002 & 230 & 213 & 17 \\
\hline 2003 & 229 & 215 & 8 \\
\hline 2004 & 239 & 231 & 5 \\
\hline 2005 & 240 & 235 & 6 \\
\hline 2006 & 241 & 235 & 7 \\
\hline 2007 & 209 & 202 & 19 \\
\hline 2008 & 215 & 196 & 15 \\
\hline 2009 & 219 & 204 & 8 \\
\hline
\end{tabular}

(Note) ${ }^{1}$ Number of HS6 products for which we have no missing values in UN Comtrade data.

(Source) Authors' calculations using data from UN Comtrade.

It can also be noted from Figure 8 that ever since 2005, prices seem to be converging whereby the Chinese price of similar products is slightly rising, while the EU export price to the US if anything is falling. Together with the evidence we supplied on the quantities sold, we believe that this reflects a reduction in vertical differentiation of EU vis-à-vis China, where the quality of Chinese products is being upgraded relative to EU products. This observation leads to the conclusion that an increase in the intensity of competition and significant quality upgrading on China's exports resulted in a loss of EU clothing products market share on international markets. 
Figure 8: Relative unit values of exports from China and EU

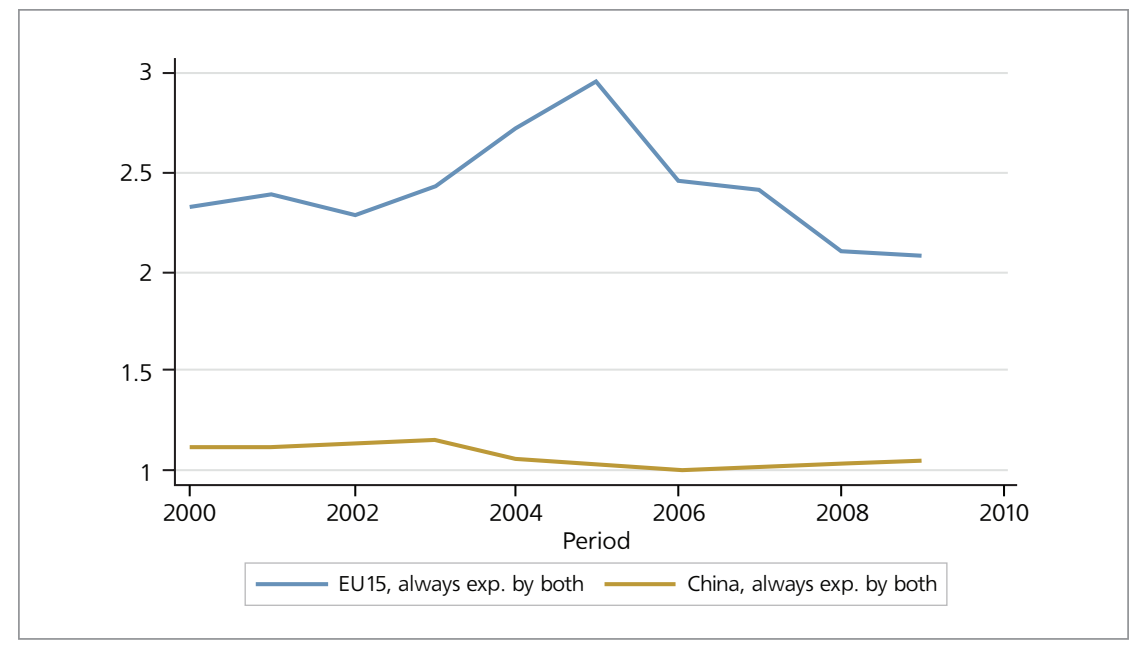

(Note) Relative unit values are defined as the export unit values of each exporter divided by the average unit value of total world exports of each product to the US. The figure presents the evolution of the median of relative unit values. The set of products is limited to those exported by both partners.

(Source) Authors' calculations using data from UN Comtrade.

\section{Conclusion}

When China entered the WTO in 2001, this was the start of a steep rise in its exports in general and in clothing in particular. As a result, traditional clothing producers and exporters, such as the EU, experienced a sharp increase in competition, not just in its own market, but also in third markets. The purpose of this paper is to see whether that rise in competition, especially after the Multi-Fiber Arrangement came to an end in 2005, has altered European product level exports in clothing in terms of prices and quantities sold.

A first question raised is whether the export product mix of Europe as a whole changed in the face of rising Chinese exports. For the clothing sector we find very little movement in Europe's export product mix. The EU is present in all HS6 digit product categories and the export share of its core products has remained remarkably stable over time.

A second question we address is whether there is any evidence of decreasing quality differences between European and Chinese products. We compared unit values for China and EU in narrowly defined product categories. The results showed that in the large majority of HS6 digit product categories, EU prices are consistently higher than Chinese prices. If we trust prices to remotely reflect quality, this leads us to conclude that European products are indeed of higher 
quality. However, a valid test for trends in the relative quality of European vis-à-vis Chinese products lies in the simultaneous comparison of trends in both prices and quantities of European and Chinese exports.

Based on the theoretical model of Foster et al., (2008) we look at prices and quantities of both EU and Chinese clothing exports to the rest of the world. Ever since the end of the Multi Fiber Arrangement, we find Chinese prices rising and EU prices falling. However, the market shares go in directions opposite to what would be expected, with Chinese market shares growing and EU market shares falling. A correlation of rising prices and rising market shares for the Chinese products in combination with lower relative prices for the EU and falling market shares, is highly suggestive of a relative increase of the quality embedded in Chinese products.

However, simply comparing EU and Chinese exports to the rest of the world at the HS6 digit level is not sufficient since observed trends could simply reflect a different country-mix and not differences in quality. So we singled out one particular destination market, the US, and results are still found to hold. Therefore we conclude that China has upgraded the quality of its exports in clothing relative to the EU products, indicating an increased quality competition between EU and China in this sector.

Received 11 December 2012, Revised 6 April 2013, Accepted 5 May 2013

\section{References}

Armington, P. (1969), “A Theory of Demand for Products Distinguished by Place of Production”, International Monetary Fund Staff Papers, XVI (1969), 159-78.

Baldwin, R. and Harrigan, J. (2011). "Zeros, quality, and space: Trade theory and trade evidence." American Economic Journal: Microeconomics 3, 60-88.

Di Comite, F., Thisse, J.-F. and Vandenbussche, H. (2011). "Verti-zontal differentiation in monopolistic competition", National Bank of Belgium Working Paper.

European Commission (2007). "Textiles, wearing apparel and leather products sector: Comprehensive sectoral analysis of emerging competences and economic activities in the European Union", Report for the European Commission, DG Employment, Social Affairs and Equal Opportunities.

Evans, Carolyn and James Harrigan. (2005). "Tight Clothing. How the Mfa Affects Asian Apparel Exports," Ito, T. and A. K. Rose, International Trade in East Asia, Nber-East Asia Seminar on Economics. University of Chicago Press, 367-90.

Fajgelbaum, Pablo, Gene M. Grossman and Elhanan Helpman (2011)," Income Distribution, Product Quality and International Trade" Journal of Political Economy, vol. 119, August.

Finger, J. M. and M. E. Kreinin.(1979). “A Measure of 'Export Similarity' and Its Possible Uses.” The Economic Journal, 89(356), 905-12.

Francois, Joseph and Julia Woerz. (2009). "Non-Linear Panel Estimation of Import Quotas: The Evolution of 
Quota Premiums under the Atc.” Journal of International Economics, 78(2), 181-91.

Foster, Lucia; John Haltiwanger and Chad Syverson.(2008). "Reallocation, Firm Turnover, and Efficiency: Selection on Productivity or Profitability?" American Economic Review, 98(1), 394-425.

Hummels, David and Peter Klenow, (2005), "The Variety and Quality of a Nation's Exports," American Economic Review, 2005, 95 (3), 704-723

Latzer, Hélène and Florian Mayneris (2011),'Trade in quality and income distribution", working paper, Université Catholique de Louvain.

Linder (1961).“An Essay on Trade and Transformation”, Almqvist \& Wiksell, Stockholm.

Melitz, M. J. and Ottaviano, G. I. P. (2008). Market size, trade, and productivity. Review of Economic Studies, 75: 295-316.

G. Mion, H. Vandenbussche and L. Zhu (2010), "Trade with China and Skill-upgrading. Evidence from Belgian firm-level data", National Bank of Belgium Working Paper, 2010-194.

Nordås, Hildegunn Kyvik (2004). "The Global Textile and Clothing Industry Post the Agreement on Textiles and Clothing "World Trade Organization Discussion Paper No. 5.

Schott, Peter K. (2008). “The Relative Sophistication of Chinese Exports.” Economic Policy, 23(53), 5-49. 